\title{
ANALISIS KADAR FLAVONOID DAN ANTIOKSIDAN EKSTRAK DAUN KENIKIR (Cosmos caudatus), RUMPUT MUTIARA (Oldenlandia corymbosa), DAN SIRSAK (Annona muricata) DENGAN TEKNIK SPEKTROMETRI
}

\author{
Wulan Tri Wahyuni ${ }^{1,2 *}$, Latifah K Darusman ${ }^{1,2}$ Pitria, Aprilani Rahmat $^{1}$ \\ ${ }^{1}$ Divisi Kimia Analitik Departemen Kimia Fakultas MIPA Institut Pertanian Bogor \\ Gedung Departemen Kimia Level 1, Jalan Tanjung No.3 Kampus IPB Dramaga, Bogor \\ ${ }^{2}$ Pusat Studi Biofarmaka Tropika LPPM Institut Pertanian Bogor \\ Kampus IPB Taman Kencana No. 3, Bogor \\ wulantriws@apps.ipb.ac.id
}

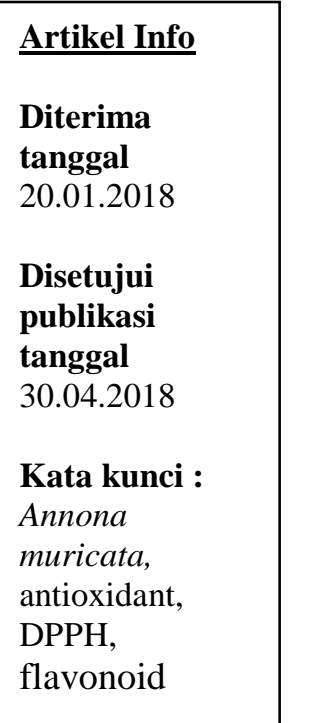

\section{ABSTRAK}

Pada penelitian ini dilakukan analisis kadar senyawa flavonoid dan penentuan aktivitas antioksidan dari ekstrak etanol daun kenikir (Cosmos caudatus), rumput mutiara (Oldenlandia corymbosa), dan sirsak (Annona muricata) dengan teknik spektrometri. Ekstrak masing-masing sampel diperoleh melalui ekstraksi dengan bantuan gelombang ultrasonik. Kadar flavonoid ditentukan dengan teknik spektrometri menggunakan kuersetin sebagai standar, sementara aktivitas antioksidan dievaluasi melalui penangkapan radikal bebas 2,2-diphenyl-1-picrylhydrazyl (DPPH). Hasil yang diperoleh menunjukkan bahwa rendemen ekstraksi daun sirsak lebih tinggi dibandingkan rumput mutiara dan kenikir. Ekstrak etanol sirsak memiliki aktivitas penangkapan radikal bebas DPPH terbaik dengan nilai $\mathrm{IC}_{50}$ sebesar $37.91 \mu \mathrm{g} / \mathrm{mL}$. Kadar flavonoid total dari ekstrak etanol sirsak tersebut ialah sebesar $1.78 \mathrm{mg}$ ekuivalen kuersetin/mg sampel, lebih rendah dibandingkan kadar flavonoid rumput mutiara dan kenikir. Hasil ini mengindikasikan bahwa aktivitas antioksidan pada ekstrak daun sirsak dimungkinkan tidak hanya berasal dari flavonoid, namun berasal dari gabungan senyawa flavonoid dengan senyawa aktif lain yang dikandungnya.

\section{ABSTRACT}

This study was evaluated the flavonoid content and antioxidant activity of ethanolic exctract of Cosmos caudatus, Oldenlandia corymbosa, and Annona muricata leaves using spectrometry technique. The ethanolic extract of each sample was obtained from sonicated assisted extraction. Flavonoid content was evaluated using spectrometry technique using quercetin as marker compound. Antioxidant activity was evaluated using radical scavenging assay of 2,2-diphenyl-1-picrylhydrazyl (DPPH). The result revealed that $A$. muricata provide higher extraction yield compare to $C$. caudatus and $O$. corymbose. Ethanolic extract of A. muricata exhibited the highest DPPH radical scavenging activity with $\mathrm{IC}_{50}$ values of 37.91 $\mu \mathrm{g} / \mathrm{mL}$. Flavonoid content of the thanolic extract of $A$. muricata was $1.78 \mathrm{mg}$ quercetin equivalent $/ \mathrm{mg}$ sample, lower than flavonoid content of $C$. caudatus and $O$. corymbose content. This result indicated that antioxidant activity of $A$. muricata may be come from synergy of flavonoid and other active compounds in the extract. 


\section{PENDAHULUAN}

Flavonoid merupakan senyawa metabolit sekunder yang terdapat dalam berbagai tanaman, termasuk di dalamnya tanaman obat. Flavonoid termasuk senyawa fenolik yang kaya akan gugus hidroksil dan dilaporkan memiliki aktivitas antioksidan. Rao et al. (2007) menyatakan bahwa efek antioksidan pada tanaman terutama disebabkan oleh senyawa fenolik, salah satunya flavonoid. Aktivitas antioksidan lazim dihubungkan dengan manfaatnya dalam terapi penyakit degeneratif, termasuk di dalamnya kanker (Birt et al. 2001).

Tanaman yang diduga memiliki potensi sebagai antioksidan ialah kenikir (Cosmos caudatus), rumput mutiara (Oldenlandia corymbosa), dan sirsak (Annona muricata). Lee dan Vairappan (2011) menyatakan ekstrak etanol kenikir memiliki potensi sebagai antioksidan dengan Ascorbic Acid Equivalent Antioxidant Capacity (AEAC) sebesar $3200.37 \pm 54.11 \mathrm{mg} \mathrm{AA} / 100 \mathrm{~g}$ ekstrak. Endrini (2011) melaporkan ekstrak metanol rumput mutiara memiliki aktivitas peredaman radikal 2,2-difenil-1-pikrilhidrazil (DPPH) dengan nilai $\mathrm{IC}_{50}$ sebesar $270.53 \mu \mathrm{g} / \mathrm{mL}$. Elisya et al. (2014) melaporkan fraksi etil asetat daun sirsak memiliki aktivitas peredaman radikal DPPH dengan nilai $\mathrm{IC}_{50}$ sebesar $94.17 \mu \mathrm{g} / \mathrm{mL}$.

Pada penelitian ini dilakukan analisis kadar flavonoid dan penentuan aktivitas antioksidan dari ekstrak etanol daun kenikir, rumput mutiara, dan sirsak. Analisis flavonoid dilakukan dengan Teknik spektrometri, sementara uji antioksidan dilakukan melalui uji penangkapan radikal bebas 2,2-diphenyl-1-picrylhydrazyl (DPPH) dan deteksi menggunakan spektrometri. Teknik spektrometri digunakan karena pengerjaanya cepat, instrumentasinya sederhana, dan ekonomis namun tetap memiliki limit deteksi dan akurasi yang dapat dibandingkan dengan teknik analisis lainnya.

\section{METODE}

\section{Alat dan Bahan}

Peralatan yang digunakan meliputi spektrofotometer UV-tampak Hitachi U-2800, microplate reader $\mathrm{EPOCH}$, microplate reader $\mathrm{BIO}-\mathrm{RAD}$, sonikator $\mathrm{AS}$ ONE frekuensi $38 \mathrm{kHz}$, penguap putar Heidolph VV 2000, oven, neraca analitik, penangas air, lampu UV, desikator, peralatan kaca, dan peranti lunak Microsoft Excel. 
Bahan-bahan yang digunakan meliputi daun kenikir (Cosmos caudatus), rumput mutiara (Oldenlandia corymbosa), dan sirsak (Annona muricata) yang diperoleh dari kebun Pusat Studi Biofarmaka Tropika, Bogor, etanol $\left(\mathrm{C}_{2} \mathrm{H}_{5} \mathrm{OH}\right) 95 \%, n$-heksana $\left(\mathrm{C}_{6} \mathrm{H}_{14}\right), n$-butanol $\left(\mathrm{C}_{4} \mathrm{H}_{9} \mathrm{OH}\right)$, kloroform $\left(\mathrm{CHCl}_{3}\right)$, aseton $\left(\mathrm{C}_{3} \mathrm{H}_{6} \mathrm{O}\right)$, etil asetat $\left(\mathrm{C}_{4} \mathrm{H}_{8} \mathrm{O}_{2}\right)$, methanol $\left(\mathrm{CH}_{3} \mathrm{OH}\right), \mathrm{mL}$ heksametilentetramina ( $\mathrm{HMT}), \mathrm{HCl}$, asam format $(\mathrm{HCOOH})$, asam asetat glasial $\left(\mathrm{CH}_{3} \mathrm{COOH}\right)$, 2,2-diphenyl-1-picrylhydrazyl (DPPH, Sigma Aldrich), serbuk asam askorbat $\left(\mathrm{C}_{6} \mathrm{H}_{8} \mathrm{O}_{6}\right.$, Sigma Aldrich), standar kuersetin $\left(\mathrm{C}_{15} \mathrm{H}_{10} \mathrm{O}_{7}\right.$, Sigma Aldrich), serbuk $\mathrm{AlCl}_{3}$, dan pelat 96-sumur.

\section{Prosedur}

\section{Preparasi Sampel}

Sampel daun kenikir, rumput mutiara, dan sirsak dikeringkan. Setelah kering, sampel daun digiling dengan ukuran 60 mesh. Kadar air serbuk sampel kemudian ditentukan dengan teknik gravimetri evolusi merujuk pada AOAC 2016.

\section{Pembuatan Ekstrak}

Serbuk sampel masing-masing ditimbang sebanyak $20 \mathrm{~g}$ kemudian diekstraksi dengan pelarut $n$-heksana sebanyak $100 \mathrm{~mL}$ untuk menghilangkan lemak. Ekstraksi dilakukan menggunakan sonikator dengan frekuensi $38 \mathrm{kHz}$ selama 3 jam, lalu dilakukan penyaringan. Residu masing-masing sampel diekstraksi menggunakan pelarut etanol 95\% sebanyak $100 \mathrm{~mL}$ menggunakan sonikator selama 3 jam, kemudian disaring. Filtrat hasil penyaringan dikumpulkan lalu dipartisi dengan pelarut kloroform (1:1), lapisan etanol dikumpulkan. Lapisan etanol yang diperoleh dipartisi kembali dengan pelarut $n$-butanol (1:1). Lapisan $n$-butanol dikumpulkan dan dipekatkan menggunakan penguap putar pada suhu $40{ }^{\circ} \mathrm{C}$ (fraksi $n$-butanol). Ekstrak etanol 95\% diperoleh dengan memekatkan filtrat etanol dari tiap sampel menggunakan penguap putar.

\section{Penentuan Kadar Flavonoid Total}

Sebanyak $200 \mathrm{mg}$ ekstrak etanol 95\% dari tiap sampel ditimbang ke dalam Erlenmeyer, ditambahkan $1 \mathrm{~mL}$ heksametilentetramina (HMT) 0.5\% b/v, $20 \mathrm{~mL}$ aseton, dan $2 \mathrm{~mL} \mathrm{HCl} \mathrm{25 \%}$ v/v. Campuran selanjutnya dihidrolisis dengan cara direfluks dalam penangas air selama 30 menit pada suhu $80^{\circ} \mathrm{C}$. Setelah dingin, campuran disaring dan filtrat hasil penyaringan dimasukkan ke 
dalam labu takar $100 \mathrm{~mL}$. Filtrat ditambahkan aseton hingga tanda tera lalu dihomogenkan. Sebanyak $20 \mathrm{~mL}$ filtrat dipipet dan dimasukkan ke dalam corong pisah, ditambahkan $20 \mathrm{~mL}$ akuades dan dipartisi sebanyak tiga kali masing-masing dengan $15 \mathrm{~mL}$ etil asetat. Fraksi etil asetat dikumpulkan dalam labu takar $50 \mathrm{~mL}$, ditambahkan etil asetat hingga tanda tera lalu dihomogenkan. Sebanyak $10 \mathrm{~mL}$ larutan tersebut dipipet dan dimasukkan ke dalam labu takar 25 $\mathrm{mL}$, ditambahkan $1 \mathrm{~mL}$ larutan berisi $2 \mathrm{~g} \mathrm{AlCl}_{3}$ dalam $100 \mathrm{~mL}$ larutan asam asetat glasial 5\% v/v (dalam metanol). Asam asetat glasial 5\% ditambahkan hingga tanda tera lalu dihomogenkan. Absorbans diukur menggunakan spektrofotometer UV-tampak pada panjang gelombang $425 \mathrm{~nm}$. Larutan standar dibuat dari standar kuersetin yang dilarutkan dengan asam asetat glasial 5\%, kemudian diencerkan menjadi berbagai konsentrasi (Depkes RI 2000).

\section{Uji Aktivitas Antioksidan Metode DPPH}

Larutan stok dari tiap sampel dibuat dengan konsentrasi $1 \mathrm{mg} / \mathrm{mL}$, kemudian diencerkan dalam etanol menjadi beberapa konsentrasi. Larutan sampel dipipet masing-masing sebanyak $100 \mu \mathrm{L}$ ke dalam pelat 96-sumur, ditambahkan $100 \mu \mathrm{L}$ larutan DPPH $125 \mu \mathrm{M}$ dalam etanol, dan diinkubasi pada suhu kamar selama 30 menit. Setelah itu, absorbans diukur menggunakan microplate reader pada panjang gelombang $517 \mathrm{~nm}$. Asam askorbat digunakan sebagai kontrol postitif, sedangkan kontrol negatifnya ialah etanol (Salazar et al. 2011). Nilai IC 50 diperoleh dari persamaan regresi grafik hubungan konsentrasi sampel uji dengan persen inhibisi. Persen inhibisi diperoleh melalui persamaan:

$$
\% \text { Inhibisi }=\frac{\text { absorbans blangko }- \text { absorbans sampel }}{\text { absorbans blangko }} \times 100 \%
$$

\section{HASIL DAN PEMBAHASAN}

\section{Identitas Sampel Uji dan Kadar Airnya Berdasarkan Analisis dengan Teknik Gravimetri Evolusi Tidak Langsung}

Sampel uji yang digunakan pada penelitian ini diperoleh dari kebun Pusat Studi Biofarmaka Tropika LPPM IPB. Identitas dari masing-masing sampel ditentukan oleh Pusat Penelitian Biologi Lembaga Ilmu Pengetahuan Indonesia. Hasil determinasi menunjukkan bahwa 
identitas ketiga sampel yang digunakan ialah Cosmos caudatus Kunth, Oldenlandia corymbose L., and Annona muricata L.

Kadar air serbuk daun kering ketiga sampel berdasarkan pengujian dengan metode gravimetri evolusi ialah sebesar 7.92; 11.14; dan $9.92 \%$ (Tabel 1). Nilai kadar air yang diperoleh digunakan sebagai faktor koreksi untuk menentukan rendemen ekstraksi berdasarkan bobot kering sampel. Berdasarkan nilai kadar air yang diperoleh, dapat dikatakan bahwa sampel dengan kadar air $<10 \%$, yaitu C. caudatus dan A. muricata telah memenuhi persyaratan simplisia untuk proses penyimpanan. Sampel dengan kadar air > 10\% tidak direkomendasikan untuk karena rentan terhadap serangan jamur dan mikroba yang umumnya mudah berkembang pada kadar air yang tinggi.

\section{Ekstrak sampel yang diperoleh dengan Ekstraksi berbantuan Gelombang Ultrasonik}

Komponen bioaktif yang diduga memiliki aktivitas antioksidan pada ketiga sampel ialah senyawa fenolik, termasuk di dalamnya flavonoid. Senyawa fenolik merupakan senyawa yang umumnya larut dalam pelarut yang bersifat polar. Oleh karena itu, pada penelitian ini ekstraksi dilakukan menggunakan etanol 95\%. Sebelum diekstraksi dengan etanol 95\%, bahan terlebih dahulu diekstraksi dengan $n$-heksana, kloroform, dan $n$-butanol. Penggunaan $n$-heksana pada tahap awal ekstraksi dimaksudkan untuk menghilangkan komponen non polar dalam sampel, sementara kloroform dan $n$-butanol digunakan untuk menghilangkan komponen semipolar. Proses ekstraksi dilakukan dengan bantuan gelombang ultrasonik $38 \mathrm{kHz}$ yang mampu merusak dinding sel tanaman sehingga mempercepat proses perpindahan massa senyawa bioaktif dari dalam sel ke pelarut (Melecchi et al. 2006). Rendemen ekstraksi disajikan pada Tabel 1. Hasil yang diperoleh menunjukkan rendemen ekstraksi daun sirsak lebih tinggi dibandingkan kenikir dan rumput mutiara.

Berdasarkan rendemen ekstraksi yang diperoleh, diketahui bahwa A. muricata memiliki rendemen ekstraksi tertinggi dibandingkan $C$. caudatus dan $O$. corymbose. Kandungan senyawa polar dalam A. muricata lebih tinggi dibandingkan kedua tanaman lainnya, diduga kandungan senyawa polar ini memiliki hubungan dengan aktivitas antioskidan dari ekstrak A. muricata yang ditentukan pada tahap berikutnya. 
Tabel 1. Kadar air sampel dan rendemen ekstraksi sampel

\begin{tabular}{lcc}
\hline \multicolumn{1}{c}{ Sampel } & Kadar Air (\%) & $\begin{array}{c}\text { Rendemen } \\
\text { Ekstraksi }(\%)\end{array}$ \\
\hline C. caudatus & $7.92 \pm 0.07$ & $10.99 \pm 0.55$ \\
O. corymbose & $11.14 \pm 0.03$ & $8.18 \pm 0.36$ \\
A. muricata & $9.92 \pm 0.05 \%$ & $12.46 \pm 0.53$ \\
\hline
\end{tabular}

\section{Kandungan Flavonoid Total Berdasarkan Analisis dengan Teknik Spektrometri}

Kandungan flavonoid dalam ekstrak etanol 95\% dari tiap sampel dievaluasi dengan metode pewarnaan $\mathrm{AlCl}_{3}$ dengan deteksi menggunakan teknik spektrometri. Tahapan analisis diawali dengan hidrolisis menggunakan asam untuk memutus ikatan gula dengan flavonoid. Flavonoid dalam bentuk aglikon kemudian dipisahkan dari gula melalui partisi cair-cair dan dikompleks dengan $\mathrm{AlCl}_{3}$. Absorbans kompleks aglikon- $\mathrm{AlCl}_{3}$ diukur dengan spektrofotometer UV-tampak (Rohaeti et al. 2011). Gambar 1 menyajikan kadar flavonoid total (mg ekuivalen kuersetin /g sampel) dari tiap ekstrak. Ekstrak kenikir memiliki kadar flavonoid total lebih besar dibandingkan rumput mutiara dan sirsak. Andarwulan et al. (2010) melaporkan kandungan senyawa flavonoid pada ekstrak metanol 50\% kenikir didominasi oleh kuersetin dan kaemferol, yakni sebesar $\pm 60 \%$ dari total senyawa flavonoid pada ekstrak tersebut.

Hasil uji flavonoid menunjukkan bahwa tidak ada korelasi yang linear antara rendemen ekstraksi dengan kandungan flavonoid total. Ekstrak sirsak menunjukkan rendemen ekstraksi lebih tinggi dibandingkan sampel yang lain, namun kandungan flavonoidnya rendah. Diduga pada ekstrak sirsak terdapat senyawa fenolik lain yang cukup ruah secara struktur sehingga tidak membentuk kompleks dengan $\mathrm{AlCl}_{3}$ saat dilakukan uji total flavonoid. Senyawa fenolik yang memiliki struktur ruah antara lain ialah senyawa tanin yang mengandung gugus gula (glikosida) maupun senyawa flavonoid yang mengikat gugus gula.

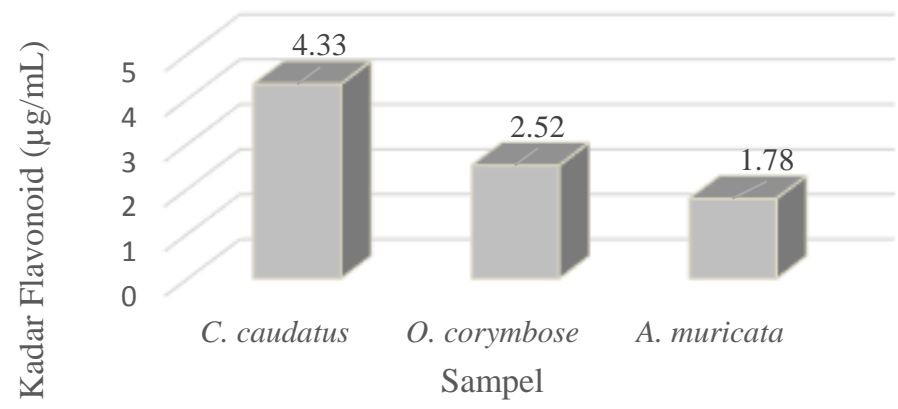

Gambar 1. Kadar flavonoid total dalam sampel berdasarkan pengukuran dengan Teknik spektrometri. 


\section{Aktivitas Penangkapan Radikal Bebas DPPH}

Senyawa 2,2-diphenyl-1-picrylhydrazyl (DPPH) merupakan radikal bebas stabil yang lazim digunakan untuk menguji aktivitas antioksidan dari senyawa bahan alam. Kelebihan metode ini ialah mudah, cepat, dan sensitif (She et al. 2010). Antioksidan memiliki kemampuan menetralisasi radikal bebas dengan menyumbangkan radikal hidrogen kepada molekul radikal bebas tersebut (Badarinath et al. 2010). Penangkapan atom hidrogen dari senyawa antioksidan oleh radikal DPPH menyebabkan DPPH tereduksi menjadi senyawa DPPH-H, dan warna larutan berubah dari ungu menjadi kuning (Szabo et al. 2006). Mekanisme penangkapan radikal bebas DPPH oleh antioksidan disajikan pada Gambar 2. Nilai konsentrasi sampel yang memberikan penghambatan sebesar 50\% terhadap radikal DPPH ( $\mathrm{IC}_{50}$ ) disajikan pada Tabel 2.

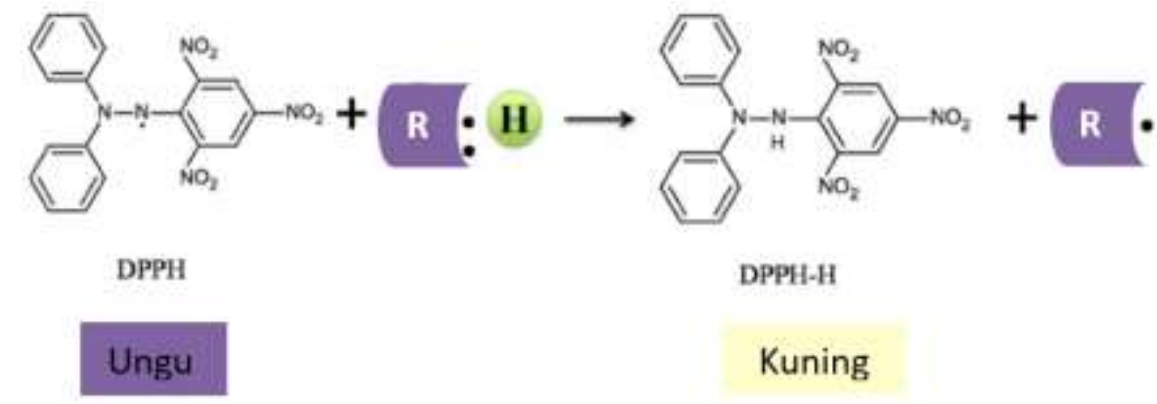

\section{R : ${ }^{H}=$ antioksidan}

Gambar 2. Mekanisme penangkapan radikal DPPH oleh antioksidan (Liang \& Kitt 2014).

Daya inhibisi terkuat terhadap radikal bebas DPPH dimiliki oleh ekstrak etanol sirsak dengan nilai $\mathrm{IC}_{50}$ sebesar $37.91 \mu \mathrm{g} / \mathrm{mL}$. Nilai ini masih lebih besar dibandingkan kontrol positif vitamin C, namun demikian menurut Zuhra (2008) suatu senyawa dikategorikan sebagai antioksidan sangat kuat jika nilai IC $\mathrm{IC}_{50}$ kurang dari $50 \mu \mathrm{g} / \mathrm{mL}$. Aktivitas antioskidan ekstrak sampel memiliki pola yang serupa dengan rendemen ekstraksinya, sampel dengan rendemen ekstraksi yang lebih tinggi juga memiliki aktivitas antioksidan yang lebih kuat. Dalam hal ini tersirat bahwa aktivitas antioksidan disumbangkan oleh senyawa yang larut dalam etanol, baik itu dari golongan fenolik maupun nonfenolik dan tidak hanya ditentukan oleh kandungan flavonoid dalam ekstrak. Menurut Rao et al (2008), selain senyawa flavonoid, efek antioksidan pada tanaman dapat disebabkan oleh senyawa fenolik lain seperti asam fenolat, tanin, dan diterpenoid fenolik. Dilaporkan ekstrak daun sirsak mengandung senyawa asetogenin yang berperan dalam aktivitas 
antioksidan dan antikanker pada tumbuhan suku Annonaceae (Lima et al. 2010). Gugus fungsi yang terdapat pada senyawa asetogenin memiliki kemampuan sebagai donor elektron bagi radikal bebas DPPH. Asetogenin merupakan senyawa poliketida yang mudah larut dalam pelarut organik (Wijaya 2012).

Tabel 2. Nilai IC50 ekstraksi sampel pada pengujian penangkapan radikal bebas DPPH

\begin{tabular}{lc}
\hline Sampel & $\mathrm{IC}_{50}(\mu \mathrm{g} / \mathrm{mL})$ \\
\hline C. caudatus & $52.81 \pm 0.30$ \\
O. corymbose & $>500$ \\
A. muricata & $37.91 \pm 0.03$ \\
Vitamin C & $4.99 \pm 0.00$ \\
\hline
\end{tabular}

\section{KESIMPULAN}

Ekstrak etanol 95\% daun sirsak memberikan rendemen ekstraksi tertinggi dan aktivitas antioksidan terbaik dibandingkan ekstrak daun kenikir dan rumput mutiara dengan nilai $\mathrm{IC}_{50}$ sebesar $37.91 \mu \mathrm{g} / \mathrm{mL}$. Kadar flavonoid total dari ekstrak tersebut ialah sebesar $1.78 \mathrm{mg}$ ekuivalen kuersetin/mg sampel, lebih rendah dibandingkan kadar flavonoid rumput mutiara dan kenikir.

\section{DAFTAR PUSTAKA}

[AOAC] Association of Official Analytical Chemist, 2016, AOAC Official Method 935.29 Loss on Drying (Moisture) in Malt Gravimetric Method. Washington DC (US): Association of Official Analytical Chemist.

[Depkes RI] Departemen Kesehatan Republik Indonesia, 2000, Parameter Standar Umum Ekstrak Tumbuhan Obat. Jakarta (ID): Depkes RI.

Andarwulan, N., Batari, R., Sandrasari, D.A., Bolling, B., Wijaya, H, 2010, Flavonoid content and antioxidant activity of vegetables from Indonesia. Food Chem. 121(2010):12311235.doi:10.1016/j.foodchem.2010.01.033.

Badarinath, A.V., Mallikarjuna, R,K,, Chetty, C.M.S., Ramkanth, S., Rajan, T.V.S., Gnanaprakash, K., 2010, A review on in-vitro antioxidant methods: comparisons, correlations and considerations. Int J PharmTech Res. 2(2):1276-1285.

Birt, D.F., Hendrich, S., Wang, W., 2001, Dietary agents in cancer prevention: flavonoids and isoflavonoids. Pharmacol Ther. 90:157-177.doi:10.1016/s0163-7258(01)00137-1.

Endrini, S., 2011, Antioxidant activity and anticarcinogenic properties of rumput mutiara (Hedyotis corymbosa (L.) Lam.) and pohpohan (Pilea trinervia (Roxb.) Wight). J Med Plant Res. 5(16):3715-3718. 
Elisya, Y., Kardono, L.B.S., Simanjutak, P., 2014, Tablet formulation of the ethyl acetate soluble exctract of soursop (Annona muricata L.) leaves. Asian J Appl Sci. 2(3):323-329.

Lee, T.K., Vairappan, C.S., 2011, Antioxidant, antibacterial and cytotoxic activities of essential oils and ethanol extracts of selected South East Asian herbs. J Med Plant Res. 5(21): 58245290.

Liang, N., Kitts, D.D., 2014, Antioxidant property of coffee components: assessment of methods that define mechanisms of action. Molecule. 19(11): 19180-19208. doi: 10.3390/molecules191119180

Lima, L.A.R.S., Pimenta, L.P.S., Boaventura, M.A.D., 2010, Acetogenins from Annona cornifolia and their antioxidant capacity. Food Chem. 122(2010):11291138.doi:10.1016/j.foodchem.2010.03.100.

Melecchi, M.I.S., Péres, V.F., Dariva, C., Zinim, C.A., Abad, F.C., Martinez, M.M., Caramã, E.B., 2006, Optimization of the sonication extraction method of Hibiscus tiliaceus L. flowers. Ultrason Sonochem. 13(3):242-250.doi:10.1016/j.ultsonch.2005.02.003.

Rao, Y.K., Geethangili, M., Fang, S.H., Tzeng, Y.M., 2007, Antioxidant and cytotoxic activities of naturally occurring phenolic and related compounds: A comparative study. Food Chem Toxicol. 45(2007):1770-1776.doi:10.1016/j.fct.2007.03.012.

Rohaeti, E., Heryanto, R., Rafi, M., Wahyuningrum, A., Darusman, L.K., 2011, Prediksi flavonoid total tempuyung (Sonchus arvensis L.) menggunakan kombinasi spektroskopi IR dengan regresi kuadrat terkecil parsial. J Kim. 5(2):101-108.

Salazar, A.R., Alejandro, R.L.L., Lopez, A.J., Alicia, A.G.B., Waksman, T.N., 2011, Antimicrobial and antioxidant activities of plants from northeast of Mexico. Evid Based Complement Altern Med. 2011:1-6.doi:10.1093/ecam/nep127.

She, G.M., Xu, C., Liu, B., Shi, R.B., 2010, Polyphenolic acids from Mint (the aerial of Mentha haplocalyx Briq.) with DPPH radical scavenging activity. J Food Sci. 75:C359C362.doi:10.1111/j.1750-3841.2010.01603.x.

Szabo, M.R., Iditoiou, C., Chambire, D., Lupea, A.X., 2006, Improved DPPH determination for antioxidant activity spectrophotometric assay. Chem Pap. 61(3):214216.doi:10.2478/s11696-007-0022-7.

Wijaya, M., 2012, Ekstraksi Annonaceous acetogenin dari daun sirsak (Annona muricata) sebagai senyawa bioaktif antikanker [skripsi]. Depok (ID): Universitas Indonesia.

Zuhra, C.F., Tarigan, J.B., Sihotang, H., 2008, Aktivitas antioksidan senyawa flavonoid dari daun katuk (Sauropus androgunus (L) Merr.). J Biol Sumatera. 